В. В. Верховський ${ }^{1}$, А. В. Самокіш, В. М. Ушань, М. А. Павленко ${ }^{2}$

${ }^{1}$ Льотна Академія Національного авіаційного університету, Кропивницький, Україна

${ }^{2}$ Харківський національний університет Повітряних Сил імені Івана Кожедуба, Харків, Україна

\title{
МЕТОДОЛОГІЯ ПРОЕКТУВАННЯ ТРЕНАЖЕРІВ З ІМЕРСИВНИМ СЕРЕДОВИЩЕМ ДЛЯ ПІДГОТОВКИ ПІЛОТІВ ЦИВІЛЬНОЇ АВІАЦІї
}

\begin{abstract}
Анотація. В статті розглянуто основні підходи до розробки нових методів проектування проектування тренажерів з імерсивним середовищем для підготовки пілотів цивільної авіації. незаперечна Незаперечно, що ефективність навчання і придбання льотним складом практичних навичок в рамках навчального процесу з використанням віртуальних тренажерів можуть запропонувати будь-які складні, недоступні або дорогі в реальному житті устаткування і матеріали, необмежений час для спроб і усвідомлення досліджуваних процесів, без небезпеки для життя. Важливим фактором, що визначає потребу віртуальних тренажерів є спосіб їх створення, що, в свою чергу, породжує задачу формування особливого середовища для їх швидкого проектування, головним чином експертами конкретної предметної області, які не мають глибоких навичок програмування. Особливо роль відіграють кордони контакту людини з віртуальним світом, що забезпечують включення і занурення в його зміст, та дають можливість ефективної і безпечної взаємодії з ним.
\end{abstract}

Ключов і сл ов а: проектування, підготовка льотного складу, авіаційний тренажер, імерсійні середовища.

\section{Постановка проблеми}

Однією з умов розвитку цивільної авіації є постійно зростаючі вимоги щодо забезпечення безпеки польотів. Відомо [1], що не менше половини авіаційних інцидентів, що сталися за останні роки в усьому світі, викликані помилками льотного складу. Також відомо [2], що поліпшення якості виконання польотних завдань на тренажерах призводить до різкого зниження ймовірності авіаційних інцидентів в льотної експлуатації повітряних суден. Очевидно, що одним з основних шляхів зменшення числа авіаційних інцидентів з вини льотного складу представляються індивідуальний (з урахуванням реальних можливостей пілота) підхід до навчання пілотів і постійний контроль за формуванням їх важливих професійних якостей. Сприяти вирішенню зазначеної проблеми може розробка нових методів проектування тренажерів для забезпечення процесу тренажерної підготовки льотного складу.

Аналіз останніх досліджень і публікацій. В роботі [3] встановлено, що суть безпосередньо тренажерної підготовки полягає в рішенні трьох видів завдань: процедурні - управління системою зв'язку, робота $з$ навігаційним обладнанням, управління паливною системою, робота з датчиками; вирішальні планування польоту, дії в екстремальних ситуаціях, визначення порядку операцій, розподіл обов'язків між членами екіпажу; прецептуально-моторні -географічне орієнтування, пілотування літака, ведення зв'язку, визначення та ідентифікація небезпеки.

В роботі [4], сукупність факторів технічного, економічного і наукового характеру зумовила формування тренажерної підготовки як щодо самостійного наукового напрямку.

Однією з умов ефективного застосування тренажерної підготовки $\epsilon$ наявність методичного та програмно-технічного забезпечення, що відповідає інтелектуальному рівню розвитку тренажерних технологій [5]. При цьому відзначимо, що основна ува- га сучасних досліджень приділяється розробці автоматизованих навчальних систем .

Так предметом наукових досліджень в роботі [6] стало підвищення ефективності професійної підготовки льотного складу при експлуатації повітряного судна нового покоління шляхом реалізації компетентнісного підходу з використанням автоматизованої навчальної системи.

В роботі [7] обгрунтовано необхідність вдосконалення методів і засобів профпідготовки льотного складу за допомогою застосування аналітичних та контролюючих програм на базі персонального комп'ютера в рамках самостійної підготовки майбутніх пілотів.

Однак сьогодні ще недостатньо розроблені та залишаються питання проектування комплексних тренажерів з зануренням у імерсійні віртуальні середовища.

Формулювання мети статті. Визначення нових методів розробки багатокористувацьких адаптивних тренажерів для підвищення рівня тренажерної підготовки пілотів цивільної авіації.

\section{Виклад основного матеріалу}

Процес підготовки пілотів цивільної авіації це керований процес взаємодії особи (пілота) з навчальним курсом (або областю знань), освоєння якого необхідно і достатньо для здійснення професійної діяльності, а саме для повітряної експлуатації літальних апаратів (ЛА). Сукупність навчальних матеріалів та зв'язків між ними, що визначають їх логічну взаємообумовленість - простір знань навчального курсу. Таким чином, процес підготовки - це діяльність особи (пілота) з освоєння простору знань як системно організованої структури, що приводить до інтеграції знань, отриманих в результаті виконання дій, і в підсумку призводить до синтезу цілісної системи знань у пілотів.

Компетентнісно-орієнтована модель процесу підготовки пілотів повинна: 
- відображати властивості цілісності простору знань курсу підготовки;

- відображати процес підготовки як процес освоєння простору знань;

- дозволяти оцінювати ступінь досягнення мети підготовки як освоєння знань та умінь в їх цілісності, а саме оволодіння професійними та загальнокультурними компетенціями.

Концептуальна модель процесу підготовки $є$ описом ключових компонент процесу підготовки, їх властивостей та взаємозв'язків, що реалізують професійні компетенції [8].

Модель простору знань $K$ можна представити так:

$$
K=\langle S, R\rangle
$$

де $S$ - множина елементів простору знань, $R$ - множина відносин щодо $S$, що забезпечують зв'язність і повноту моделі простору знань $K$. навичок

Виділяють чотири стадії формування льотних

У початковий період (перша стадія) підготовки пілотування в складному польотному завданні, коли навички ще не сформовані, освоєння програми дій, прийомів реалізації кожної робочої операції і їх значимості пов'язане 3 неадекватною складністю завдань, зростанням рівня фізіологічних реакцій.

На другій стадії, у міру вдосконалення рухових навичок, структури розподілення та переключення уваги, процесів переробки інформації, енерговитрати організму та рівень нервово-емоційної напруги пілота знижуються, що проявляється в послабленні фізіологічних реакцій.

Третя стадія характеризується високою і стабільною якістю пілотування, оптимальним і відносно стійким рівнем фізіологічних реакцій організму, відповідним складності виконуваного завдання, що свідчить про високу ефективність фізіологічних витрат і достатньою натренованості пілота. Зростають резервні можливості пілота 3 виконання додаткової завдання в процесі пілотування.

Четверта стадія може виявлятися тоді, коли процес відпрацювання конкретної вправи надмірно затягнувся, і в льотного складу знижується інтерес та з'являється байдужість до тренувань. При цьому поряд зі зниженням рівня нервово-емоційної напруги відзначається збільшення помилок управління.

Професійна льотна діяльність забезпечує формування складних навичок і умінь взаємодії пілота 3 ЛА в умовах впливу різноманітних внутрішніх і зовнішніх факторів польоту. Навички, що формуються, закріплюються і підтримуються в процесі льотної діяльності, називають льотними навичками. Питання формування льотних навичок розглядаються в льотно-методичному (психолого-педагогічному), інженерно-психологічному, психофізіологічному та медичному аспектах. Навички та вміння пілотування можуть характеризуватися умінням пілота правильно вибирати і точно витримувати значення керованих параметрів польоту на кожній окремій ділянці пілотування. За цією ознакою виділяють комплекси умінь і навичок пілотування. Дії пілота з ор- ганами управління в кабіні, в залежності від виконуваного елемента пілотування, характеризуються комплексом льотних операторських навичок та умінь. Льотні навички характеризуються матеріальними ознаками, в ролі яких виступають параметри якості пілотування, руху органами управління і параметрами стану самого пілота.

Необхідні навички пілотування відпрацьовуються в результаті багаторазових повторень при виконанні спеціально продуманих вправ в ході навчання на тренажері та в польоті. Іншими словами, виробляється динамічний стереотип для різних умов польоту. Труднощі підготовки можуть виникати при виробленні умінь швидко орієнтуватися в складній обстановці, в придбанні навичок без зволікання приймати правильне, а часом єдине вірне рішення.

Підготовка льотного складу до пілотування ЛА має проводитися в строго визначеної послідовності і за спеціальними програмами, виконання яких повинно бути чітко визначено методичними аналізами по кожному типу ЛА. Процес підготовки льотного складу до пілотування проводиться по етапах в наступній послідовності:

- теоретичні заняття в класі;

- практичні заняття на тренажері кабінних процедур в кабіні ЛА або в статичному положенні на комплексному тренажері літака, в крайньому випадку - в кабіні ЛА;

- імітації польоту в процесі пілотування на комплексному тренажері;

- польоти в районі аеродрому.

Тренажерна підготовка, як етап, підготовки до льотної діяльності, вирішує завдання остаточного формування готовності майбутнього пілота до льотної практики, використовуючи наявні можливості діагностики і коригування професійно важливих якостей.

Застосування на цьому етапі досягнень авіаційної педагогіки та психології дозволяє підвищити ефективність процесу формування професійної надійності. Тренажерна підготовка є специфічним етапом професійної підготовки пілотів. Як показали дослідження [9-11], саме тренажерні засоби підготовки здатні бути тим інструментарієм, за допомогою якого можливий всебічний підхід до підготовки пілотів цивільної авіації, що дозволяе формувати знання, навички та вміння, що важливі для професійних якостей та компетенцій пілотів.

У загальному випадку тренажер літака являє собою спеціалізований комплекс технічних засобів, що моделюють процес пілотування в наземних умовах з високим ступенем подібності. Тренажер є універсальним засобом наземної підготовки льотного складу і служить для вирішення наступних основних завдань:

- ознайомлення $з$ діями органів управління літального апарату і його систем;

- відпрацювання навичок $з$ оцінки обстановки і прийняття рішення в особливих випадках польоту і при виконанні тактичних завдань;

- відпрацювання навичок дій в особливих випадках в польоті; 
- відпрацювання навичок дій органами управління за елементами польотних завдань;

- автоматизована постановка завдання на льотну зміну;

- самостійна підготовка до польотів;

- груповий контроль готовності до виконання польотного завдання;

- розбір польотів індивідуальний і в складі льотної групи.

Ефективність підготовки льотного складу на авіаційних тренажерах визначається наступними положеннями:

- на тренажері простіше і безпечніше, ніж в польоті, відпрацьовувати багато операцій, багаторазово їх повторюючи;

- на тренажері безпечно відпрацьовувати дії льотного складу при моделюванні аварійних ситуацій, які неможливо або небезпечно створювати в реальному польоті;

- експлуатація тренажера набагато економніше, ніж літака.

Підготовка на тренажерах дає широкі можливості в дослідженні нових прогресивних методів і прийомів навчання, дозволяє проводити аналіз допущених помилок в техніці пілотування і експлуатації систем літака. Авіаційний (пілотажний) тренажер - це імітатор польоту, призначений для наземної підготовки пілотів. В авіаційному тренажері імітується динаміка польоту та робота систем ЛА за допомогою спеціальних моделей, реалізованих в програмному забезпеченні обчислювального комплексу тренажера.

Тренажери цивільних ЛА мають більш високий рівень досконалості, оскільки в цивільній авіації діють жорсткі стандарти JAR-FSTD та ICAO 9625 [12], що детально визначають відповідність тренажерної моделі реальному ЛА. Авіаційні тренажери можна розділити на чотири основні групи: Full Mission Simulator (FMS), Full Flight Simulator (FFS), Flight Training Device (FTD), Flight Procedures Training Device (FPTD) [12]. У сучасній практиці підготовки пілотів цивільної авіації найбільшого поширення набули комплексні тренажери (FFS) i процедурні тренажери (FPTD).

Комплексними тренажерами називають тренажери, обладнані системою рухливості. Це тренажери найвищого рівня. Кабіна комплексного тренажера виконується у вигляді реальної кабіни літального апарату. На комплексні тренажери встановлюються передові системи візуалізації. Такі тренажери реалізують навчання на більш досконалому рівні і мають такі основні властивості: максимальне наближення умов діяльності льотчика до умов реальної діяльності в польоті; забезпечення відпрацювання на імітаторі в цілому всіх завдань реальної діяльності льотчика, яку він здійснює в польоті; забезпечення можливості об'єктивного контролю результатів всіх відпрацьовуються на комплексному симуляторі завдань в цілому. Комплексний тренажер є найвищим рівнем технічних засобів навчання для підготовки льотного складу і має можливість відпрацювання всіх без виключення режимів експлуатації ЛА.
У традиційному «тренажерному» напрямку розвитку технічних засобів навчання проводяться дослідження щодо зниження потреби в дорогих комплексних авіаційних тренажерах. Вважається, що це може бути досягнуто за рахунок застосування тренажерних систем, до складу яких повинні входити різні за рівнем складності пристрою, починаючи від найпростіших процедурних і спеціалізованих тренажерів і закінчуючи комплексними, які об'єднуються на модульних принципах [4].

Віртуальне оточення повністю відокремлює користувача від реальної реальності (RR) с допомогою VR-шолома, навушників, джойстиків, контролерів, рукавичок, інших пристроїв і замінює їі симуляцією. Віртуальна реальність визначається як інтерактивна тривимірна графічна сцена, яка використовує спеціалізовану технологію відображення, занурює користувача в реальному часі в створений світ, 3 прямим маніпулюванням об'єктами в модельному просторі. Системи віртуальної реальності дозволяють підтримувати інтерактивну взаємодію 3 високим ступенем занурення.

Технічна реалізація "віртуальної реальності" змінювалася слідом за розвитком комп'ютерів і засобів відображення. На зміну експериментальних додатків 1980-х прийшли складні програмноапаратні комплекси 1990-х для військових, промислових і дослідницьких завдань. Спочатку це була дорогі стереоскопічні установки для вузькоспеціального застосування.

3 2000-х років зростання продуктивності графічних процесорів забезпечило перехід технології віртуальної реальності у все більш масову нішу, вона стала доступна для будь-яких систем підготовки. Подолання недоліків VR-технології наведено на рис. 1.

Відомі такі типи віртуальної реальності:

- VR без занурення;

- VR зі спільною інфраструктурою;

- VR $з$ ефектом повного занурення.

Незважаючи на те, що недоліки VR-технології ще не подолані повністю, сьогодні навряд чи знайдеться область діяльності, де ще немає прикладів використання віртуальної реальності, зокрема, в навчанні - це різноманітні тренажерні системи, призначені для навчання професійним навичкам.

Віртуальна реальність $з$ ефектом занурення вимагає присутності деяких факторів, таких, як:

1) наявність досить продуктивної техніки, здатної швидко розпізнавати дії суб'єкта і реагувати на них в режимі реального часу;

2) реалістична, деталізована симуляція світу 3 ефективним поданням об'єктів у віртуальному середовищі;

3) спеціальне обладнання, включаючи новітні імерсійні середовища.

Одним 3 найважливіших властивостей віртуальної реальності $є$ імерсійність - ступінь занурення суб'єкта в віртуальний світ, що досягається шляхом генерації максимальної схожості останнього 3 реальним світом за допомогою симуляції. Перевагою симуляції над імітацією $є$ копіювання об'єктів і по- 
дій на рівні моделі. Віртуальна реальність симулює щось, що не існує в реальності. Таке занурення у визначенні, штучно синтезовані умови віртуальної реальності називають імерсійним середовищем.

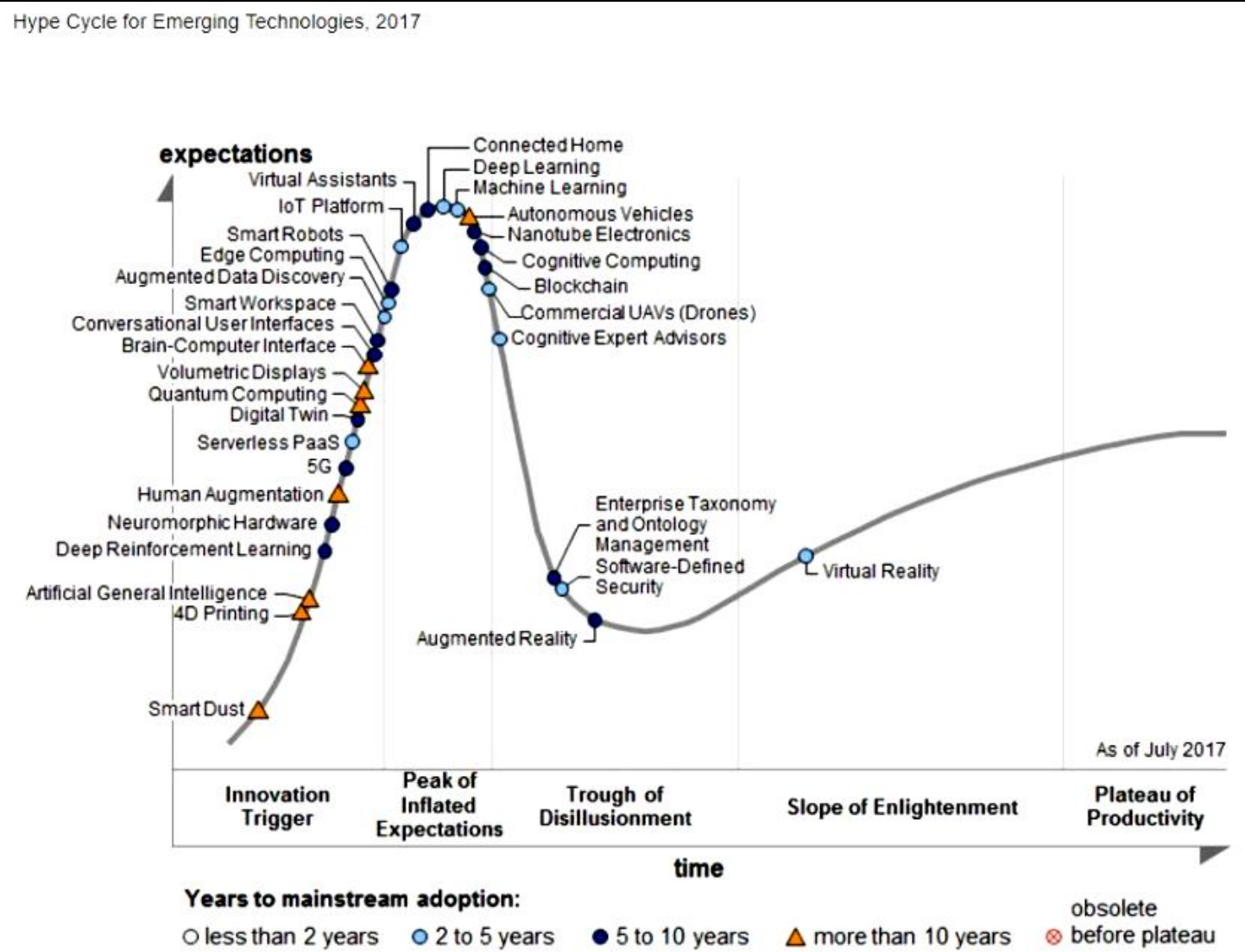

Note: PaaS = platform as a service, UAVs = unmanned aerial vehicles

Source: Gartner (July 2017)

Рис. 1. Фаза подолання недоліків VR-технології

У дослідженнях інженерно-психологічних аспектів віртуальної реальності виділяють наступні властивості імерсійного середовища: надмірність (властивість, що дозволяє забезпечити множинність взаємин із середовищем); спостережність (проявляється в процесі конструювання дійсності - середовищем може бути тільки те, що спостерігається, навіть якщо воно присутнє в фізичної реальності); конструйованість (або доступність до когнітивного досвіду, що характеризує певний ступінь готовності суб'єкта до включення в середовище); насиченість (насичене середовище забезпечує широкий спектр впливів на льотний склад за допомогою багатоваріантності відносин); автономність існування (середовище має свої самостійної історією, незалежної від зовнішнього середовища); пластичність (середа 3 легкістю може приймати і забезпечувати стабільність форм, обумовлених різноманіттям змісту); синхронізуються (середа має локальну самоорганізацію і тимчасові якості всіх елементів середовища); позасуб'єктна просторова локалізація (розміщення незалежно від суб'єкта); векторність (спрямований навчальний ефект в певному діапазоні завдань); цілісність (єдність середовища 3 властивостями суб'єкта, при якому суб'єкт сприймає середу як світ діяльності); мотивогенність (можливість впливу середовища на мотивацію льотного складу); інтерактивність (ступінь, до якої користувач в змозі брати участь в зміні і формуванні встановленої середовища в режимі реального часу); імерсійні (можливості середовища залучати користувача і орієнтувати його в системі відносин, яка визначається вмістом середовища); присутність (висловлює почуття знаходження людини в певному середовищі; відміну від імерсійні полягає в тому, що імерсійні більш пов'язана із зовнішніми і фізичними характеристиками, а присутність визначає внутрішні, суб'єктивні компоненти). Компонентами феномена присутності прийнято вважати залученість і занурення.

Загальною характеристикою навчальних тренажерів в віртуальних імерсійних середовищах $\epsilon$ сильна залежність ефективності навчання від якості системи, включаючи сценарій і впровадження практик підвищення імерсійності, а також від того, як користувач працює 3 системою. Загальна структура тренажера підготовки пілотів цивільної авіації з віртуальним імерсійним середовищем зображена на рис. 2.

При створенні авіаційних тренажерів із зануренням в імерсійні середовища, для більшої ефекти- 
вності навчання необхідно використовувати імітаційні або ситуаційні моделі, причому підходять як розімкнуті, так і траєкторні методи управління навчанням, при можливості з вибудовуванням адаптивних підходів (рис. 3).

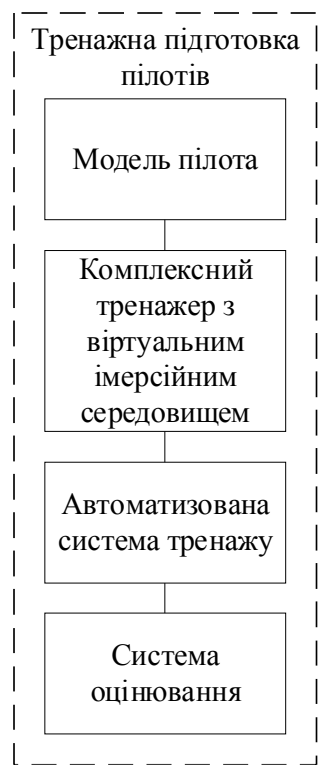

Рис. 2. Загальна структура тренажера підготовки пілотів цивільної авіації

Після аналізу параметрів, що впливають на рівень (ступінь) імерсивності середовищ, можна зробити наступні висновки:

1. Віртуальне середовище надає абсолютно різний вплив на різних суб'єктів підготовки, зокрема, через неоднакові параметри організму і різного життєвого досвіду пілотів.

2. Наявне обладнання для віртуальних середовищ, безсумнівно, підвищує імерсивність, однак не $\epsilon$ досконалим через похибки технічних засобів. Обладнання - на даній технологічній фазі є недостатньо комфортним для максимального занурення.
3. Кіберболезнь $є$ серйозним фактором, що знижує імерсивні середовища, вона важко повністю подавляема за недосконалістю існуючих технологій і індивідуальною реакцією користувачів на віртуальні середовища.

4. На сьогоднішній день $є$ достатня кількість експериментальних даних про залучення різних областей кори головного мозку в виникнення СЕКЦА, а також виявлені деякі зміни в динаміці мозкової активності при переживанні даної ілюзії. Однак, як відзначають багато авторів, результати цих досліджень часто не узгоджуються між собою через відмінності в використовуваної стимуляції і методів оцінки вираженості ілюзії (див., Наприклад, [128]).

5. Ізоляція віртуального середовища від фізичної і симуляція власного пересування створюють складність для підвищення імерсивні середовища, так як найбільш імерсивні пересування вимагає великих вільних просторів.

6. Максимальний ефект присутності так само на даний момент не можна досягти через те, що сучасні технології зачіпають не всі органи чуття людини, не ідеально симулюють деякі інші відчуття (зокрема, дотикові, наприклад, температура, вага віртуальних предметів, їх текстура).

7. Використання для оцінки імерсивні і присутності віртуальної навчального середовища суб'єктивних результатів тестів (див., Наприклад [61]) не дозволяють 3 великою точністю оцінити, який рівень присутності відчуває користувач, який перебуває у віртуальному середовищі.

Таким чином, основна гіпотеза така - для кожного окремого суб'єкта імерсійні середовища повинні підтримуватися унікальні умови і виконуватися певні чинники, які виявляються за допомогою обстежень суб'єкта на його специфічні особливості організму, аналізу когнітивних функцій, при яких рівень імерсії, який вимірюється за допомогою існуючих методів оцінки ефекту присутності, буде мати максимальне значення.

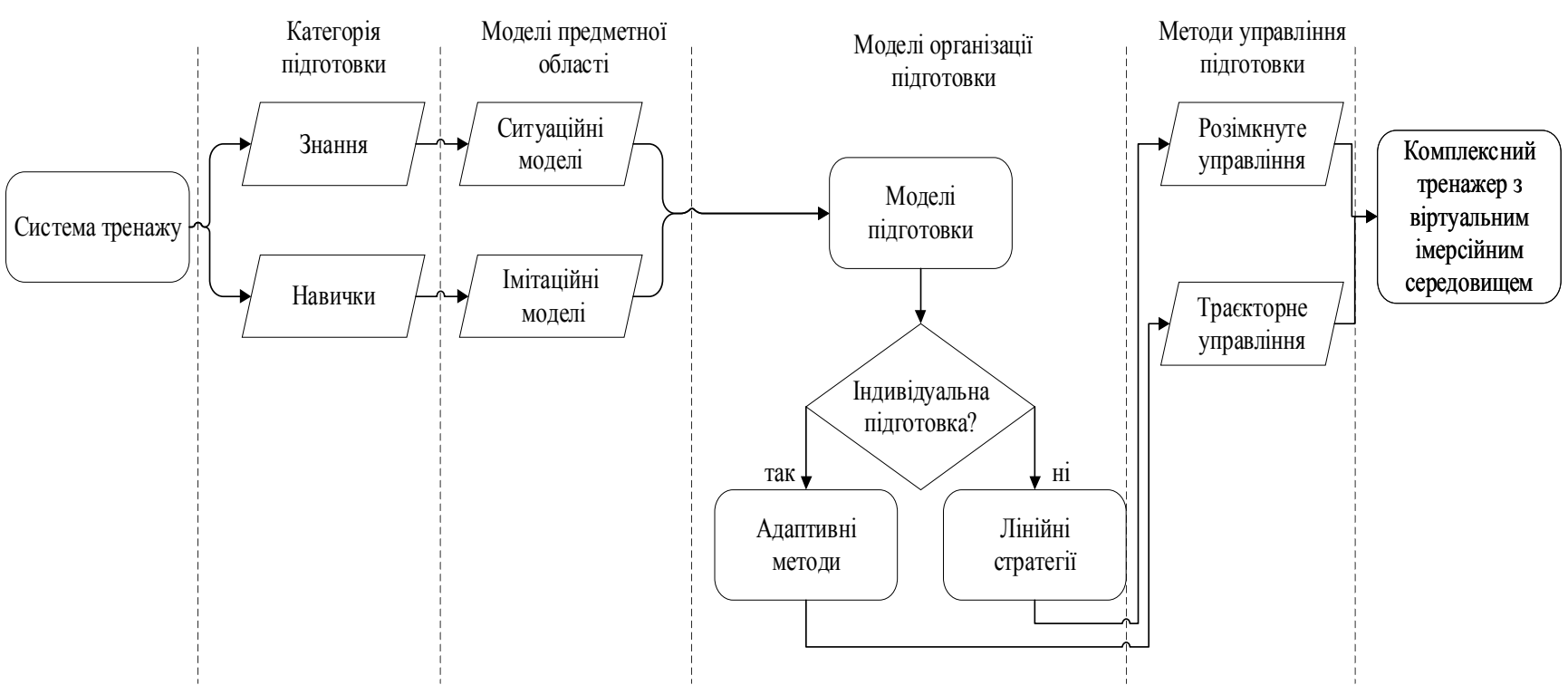

Рис. 3. Комплексна модель організації та управління підготовкою на комплексному тренажері з віртуальним імерсійним середовищем 


\section{Висновки}

Серед зазначених засобів професійної підготовки льотного складу особливе місце займає тренажерна підготовка, що має найбільш тісний зв'язок 3 успіхами льотного навчання і формуванням високої надійності пілота в польоті. Саме тренажерні засоби навчання здатні стати тим інструментарієм, за допомогою якого можливий всебічний підхід до підготовки льотного складу, що дозволяє формувати знання, навички та вміння, а також професійно важливі якості та компетенції майбутніх пілотів.

Проведений аналіз типів віртуальної реальності, технік підвищення імерсії та методів, що застосовуються для реалізації високо реалістичних вірту- альних середовищ, а також існуючого інструментарію засобів виведення інформації та зворотного зв'язку, можна зробити кілька висновків не розроблено методи оцінки імерсії конкретного індивідуума в конкретному віртуальному середовищі. Запропоновано застосування для підготовки пілотів цивільної авіації комплексних тренажерів 3 імерсійним середовищем, що дозволяє враховувати активність льотного складу в процесі професійної підготовки. Для вирішення завдань, що виникають в процесі розробки навчально-тренувальних засобів для підготовки льотного складу, потрібні зміни і доповнення в методології проектування, що враховують характер взаємодій в системі «пілот - літальний апарат середовище».

\section{СПИСОК ЛІТЕРАТУРИ}

1. Состояние безопасности полетов в мире. - [Электронный pecypc]. -http://www.icao.int/safety/Documents/ICAO Stateof-Global-Safety web RU.pdf.

2. Картамышев П. В. Методика летного обучения / П. В. Картамышев, М. В. Игнатович, А. И. Оркин. - М.: Транспорт, 1987. $-278 \mathrm{c}$.

3. Макаров Р. Н. Теоретические основы профессиональной авиационной педагогики / [Макаров Р. Н., Герасименко Л. В., Нидзий Н. А, Стрелец И. В.]. - М. : МАПЧАК, 2000. - 325 с.

4. Кемалов Б. К. Разработка интегрированных средств представления знаний в системах машинного обучения авиационных специалистов : автореф. дис. ... канд. техн. наук / Б. Кемалов - Пенза, 2012. - 19 с.

5. Казачкин Б. И. Авиационные тренажеры как связующее звено между наземной и летной подготовкой / Б. И. Казачкин. - Монино , 1999. - 160 с.

6. Косачевский С. Г. Применение теории трансформационного обучения для разработки автоматизированных обучающих систем подготовки летного состава / С. Г. Косачевский // Научный вестник МГТУ ГА. Серия: Аэромеханика и прочность. 2007. - № 111.- С. 172-175.

7. Желтухин В. В. Автоматизированные обучающие системы в сфере управления профессиональной подготовкой летного состава. Роль предтре-нажерной подготовки. // Межвузовский сборник научных трудов. СПб., Академия гражданской авиации, 1999. T. IV. - С. 192-200.

8. Гринченко, С. Создатели виртуальности: краткий обзор производителей тренажёрных систем [Текст] / С. Гринченко // Defense Express. Экспорт оружия и оборонный комплекс Украины. - 2008. - № 4. - C. 35-37.

9. Кушнир О. А. Тренажёрная подготовка будущих пилотов в интегративной системе диагностики и корригирования профессионально важных качеств / О. А. Кушнир // Проблеми інженерно-педагогічної освіти. - Харків : УППА, 2008. - № 22-23. - С. 356-365.

10. Макаров Р. Н. Психологическая подготовка летного состава средствами наземнойподготовки / Р. Макаров. - М. : Изд-во ВВА им. Ю. А. Гагарина, 1984. - 200 с.

11. Макаров Р. Н. Основы формирования профессиональной надежности летного состава гражданской авиации: Учебное пособие / Р. Н. Макаров. - М. : Воздушный транспорт, 1990. - 384 с.

12. Макаров Р. Н. Основы формирования профессиональной надежности летного состава гражданской авиации: Учебное пособие / Р. Н. Макаров. - М. : Воздушный транспорт, 1990. - 384 с.

Received (Надійшла) 23.09.2020

Accepted for publication (Прийнята до друку) 28.10.2020

\section{Methodology for designing simulators with immersive medium for training pilots of civil aviation V. Verkhovsky, A. Samokish, V. Wushan, M. Pavlenko}

Abstract. The article discusses the main approaches to the development of new design methods for designing simulators with an immersive environment for training civil aviation pilots. Indisputable It is indisputable that the effectiveness of training and the acquisition of practical skills by the flight crew within the training process using virtual simulators can offer any equipment and materials that are complex, inaccessible or expensive in real life, unlimited time for testing and awareness of the studied processes, without danger to life. An important factor that determines the need for virtual simulators is the way of their creation, which, in turn, gives rise to the task of forming a special environment for their rapid design, mainly by experts in a specific subject area who do not have deep programming skills. A particular role is played by the boundaries of human contact with the virtual world, which ensure inclusion and immersion in its content, and enable effective and safe interaction with it. The training methods are widely accepted in the training of pilots; in this situation, it also has serious limitations due to the need to perform a significant amount of algorithmic operations that are incomprehensible to the free staff and therefore cause an "information shock". A way out of this situation is the use of special training tools that form an artificial learning environment and simulate the main elements of the real benefits and conditions for using the studied technology. The simulator in simulated conditions allows you to implement the activities of the privileged composition, the implementation of which on real equipment is impossible according to economic criteria or is associated with a threat to life. In some cases, simulator training is the only method of ensuring the professional readiness of the pilot.

Keywords : design, training of flight personnel, aircraft simulator, immersion environment. 